\title{
Effect of Newcastle disease virus level of infection on embryonic length, embryonic death, and protein profile changes
}

\author{
Dahliatul Qosimah ${ }^{1}$, Sri Murwani ${ }^{1}$, Edhy Sudjarwo ${ }^{2}$ and M. Arfan Lesmana ${ }^{3}$
}

1. Laboratory of Microbiology and Immunology, Faculty of Veterinary Medicine, Brawijaya University, Indonesia; 2. Department of Poultry Production, Faculty of Animal Husbandry, Brawijaya University, Indonesia; 3. Animal Clinic, Faculty of Veterinary Medicine, Brawijaya University, Indonesia. Corresponding author: Dahliatul Qosimah, e-mail: dahliatulqosimah@gmail.com Co-authors: SM: muratinia@ub.ac.id, ES: sudjarwoedhy@gmail.com, MAL: arfan142002@yahoo.com Received: 09-04-2018, Accepted: 30-07-2018, Published online: 24-09-2018

doi: 10.14202/vetworld.2018.1316-1320 How to cite this article: Qosimah D, Murwani S, Sudjarwo E, Lesmana MA (2018) Effect of Newcastle disease virus level of infection on embryonic length, embryonic death, and protein profile changes, Veterinary World, 11(9): 1316-1320.

\begin{abstract}
Background and Aim: Newcastle disease virus (NDV) is an obligate intracellular parasite. Virus can only live on living cells. The embryonated chicken eggs (ECEs) are one of the growth media of virus that is a cheap, easy to do, and accurate for showing patterns of virus change in the host. Higher virus titers indicate the higher number of viruses and more virulent to infect host. This research aimed to investigate the effect of different level of NDV titer infection in ECEs on protein profile, embryonic length, mortality, and pathological change.
\end{abstract}

Materials and Methods: The study used a completely randomized design of six treatments and seven replications. The treatments were different level of NDV titer infection in allantoic fluid (AF) of 9-11 days ECEs, i.e., P1 $=2^{0}, \mathrm{P} 2=2^{6}$, $\mathrm{P} 3=2^{7}, \mathrm{P} 4=2^{8}, \mathrm{P} 5=2^{9}$, and $\mathrm{P} 6=2^{10}$ hemagglutination unit (HAU). All samples were separated by sodium dodecyl sulfatepolyacrylamide gel electrophoresis. Data were analyzed using one-way ANOVA with $\mathrm{p}=0.05$ for length of the embryo and descriptive analysis for embryo mortality, pathology change, and protein band.

Results: The result showed that protein profile of NDV-infected ECEs of all different levels is more complex than protein profile of no NDV-infected ECEs. NDV infected of all different levels showed longer size embryo, higher mortality embryo at the first 2 days, and higher occurrence of hemorrhagic in all part of bodies of embryo than those of no NDV infected.

Conclusion: It was concluded that NDV infection of all different level decreased health conditions of chicken embryo of ECEs of 9-11 days old. Different level of NDV infection of ECEs of 9-11 days old showed no significantly different embryo profiles. However, all of the NDV-infected embryos were shorter, death on the 2nd day, and suffered more hemorrhage on all body surfaces than uninfected NDV embryos.

Keywords: embryo, Newcastle disease, pathological change, protein, titer, virus.

\section{Introduction}

Newcastle disease (ND) is caused by ND virus (NDV) which is a genus of Avulavirus and Paramyxoviridae family. The incidence of ND that attacks poultry shows manifestations of gastrointestinal, respiratory, and neurological disorders that cause deaths of up to $100 \%$ depending on the viral pathotype $[1,2]$. ND virus is highly contagious and causes huge economic losses in the poultry industry due to the decrease in production and quality of eggs and chicken performance [3]. Virulent of NDV strains are endemic to poultry in most of Asia, Africa, and some northern and southern states of America. This disease can also be transmitted to humans. ND disease first epidemic in Java Island, Indonesia in 1926 and spread pandemically

Copyright: Qosimah, et al. Open Access. This article is distributed under the terms of the Creative Commons Attribution 4.0 International License (http://creativecommons.org/licenses/ by/4.0/), which permits unrestricted use, distribution, and reproduction in any medium, provided you give appropriate credit to the original author(s) and the source, provide a link to the Creative Commons license, and indicate if changes were made. The Creative Commons Public Domain Dedication waiver (http:// creativecommons.org/publicdomain/zero/1.0/) applies to the data made available in this article, unless otherwise stated. in chickens and other poultry subsequently found in Newcastle upon Tyne, England in 1927 [4,5].

NDVs can invade the host through inhalation, fecal-oral transmission routes, excretion of infected poultry, and contact through virus-contaminated equipment [2]. Isolation of the ND virus can come from fecal and nasopharyngeal swabs, as well as organs. ND virus can be grown in embryonated chicken eggs (ECEs) and cultured chicken embryo fibroblast cells [6].

NDV virulence detection is important for vaccination and eradication programs [7]. This study aimed to evaluate the effect of administering various doses of NDV infection to pathogenicity cause death and organ disorders in ECEs and as well as protein profiles in allantoic fluid (AF) as the basic research reference for the development of biomolecular research.

\section{Materials and Methods}

\section{Ethical approval}

This research had received ethical approval from the Ethics Commission of Faculty of Medicine of Brawijaya University, Malang (Ethic Certificates No 803-KEP-UB). 


\section{Research method}

The study used a completely randomized design of six treatments and seven replications. The treatments were different level of NDV infection of 9-11 days ECEs, i.e., $\mathrm{P} 1=2^{0}, \mathrm{P} 2=2^{6}, \mathrm{P} 3=2^{7}, \mathrm{P} 4=2^{8}, \mathrm{P} 5=2^{9}$, and $\mathrm{P} 6=2^{10}$ hemagglutination unit (HAU). Protein profile, embryonic length, mortality, and pathological change were observed, and the data were descriptively analyzed and using analysis of variance.

\section{Propagation and harvest of NDV in ECEs}

Propagation of NDV in ECEs of 9-11 days old is negative against NDV antibodies (based on HA and hemagglutination inhibition $[\mathrm{HI}]$ test that showed titer of antibody negative). Based on observation using polymerase chain reaction methods on AF of ECEs, it was identified that NDV had F protein with a nucleotide length of $362 \mathrm{bP}$. Furthermore, the ECEs were put in egg incubator at $37^{\circ} \mathrm{C}$ and observed daily for viral death through light observation. The optimum standard temperature for embryo growth is $37.5-37.8^{\circ} \mathrm{C}$ [8]. The dead embryo shows no movement and black color. Embryos that have not shown death until the $7^{\text {th }}$ day, the embryo is forced off by being placed in the refrigerator at a temperature of $4^{\circ} \mathrm{C}$. Collection of allantoic fluid from eggs infected by a virus was then measured by viral titers using HA test and $\mathrm{HI}$ test $[9,10]$. The stock of $\mathrm{ND}$ viruses in $\mathrm{AF}$ was stored at $-20^{\circ} \mathrm{C}$ until use [11].

\section{NDV identification using HA test}

HA test was used to find out the virus that has hemagglutinin protein to agglutinate $1 \%$ chicken erythrocytes. The samples used were AF from viral infection yield to ECEs. HA titers exhibit the highest dilution indicating viral proteins that are still capable of agglutinating erythrocytes $[12,13]$. Samples were inserted in a 96-well microtiter plate with a "V" shape base. Test was done in duplo.

\section{NDV identification using HI Test}

HI test was performed according to OIE [9] using viral antigen ND 4 HA unit per well using 1\% erythrocyte chicken. HI titers show the highest dilution of specific antibodies that are capable of inhibiting viruses to agglutinate the virus expressed as $\log 2$. The test was repeated twice.

\section{Mean death time test}

NDV with titer variation of $10^{6}-10^{10}$ was infected on seven ECEs for each treatment subsequently incubated at $37^{\circ} \mathrm{C}$. Embryonic death was observed daily for 7 days and evaluated through candling and recorded embryonic mortality. The highest dilution in which all embryos die was calculated as mean lethal dose [7]. Viral virulence was categorized by three classifications: Embryo mortality $<60$ h (Velogenic), 60-90 h (Mesogenic), and $>90 \mathrm{~h}$ (Lentogenic) [3].

\section{Sodium dodecyl sulfate-polyacrylamide gel electro- phoresis (SDS-PAGE) test}

Protein profile of AF of infected NDV embryo of ECEs was analyzed by SDS-PAGE test. A total of $5 \mu \mathrm{l}$ of AF was introduced into $7.5 \%$ stacking gel and $12 \%$ separating gel, then electrophoresis was run at room temperature with a voltage of $200 \mathrm{~V}$. After electrophoresis, the gel was stained using a $0.1 \%$ Coomassie blue solution for $24 \mathrm{~h}$ and destained using methanol and glacial acetic acid for approximately $3 \mathrm{~h}[14,15]$.

\section{Results}

\section{Protein profile of AF from normal and NDV-infected embryo of ECEs}

Figure-1 presents the protein profile of AF of NDV-infected embryo of ECEs (B) as compared to those of AF from normal or no NDV-infected embryo of embryonated chicken eggs (B; [16]). All AFs of NDV-infected embryo of all different level showed same protein profile with a molecular weight ranged from 7.29 KDa to 135.28 KDa (Figure-1b), which were different from those AF of normal or no NDVinfected embryo (Figure-1a) [16].

\section{Influence of NDV titer level against embryo size}

The results showed that level of NDV titer infection on ECEs 9-11 days of age did not show significantly different on embryo size but greater than those on non-infected NVD embryo (Table-1).

\section{Influence of NDV titer level against of embryonic pathology}

Figure-2 showed gross pathology in all treatments. All NDV-infected embryos showed hemorrhage in all parts of the body, whereas no NDV-infected ones showed healthy embryo and no hemorrhage.

\section{Discussion}

Protein profile of no NDV-infected chicken embryos is more complex than the protein profile of NDV-infected chicken embryos of all different levels. According to Dewi and Surachmi [17] that there are many serine protease-containing enzymes such as trypsin in the AF of ECEs that were infected with NDV. The enzymes degrade specific proteins on the molecular weight so that the gel will not absorb color and will be visualized as a band that is not stained.

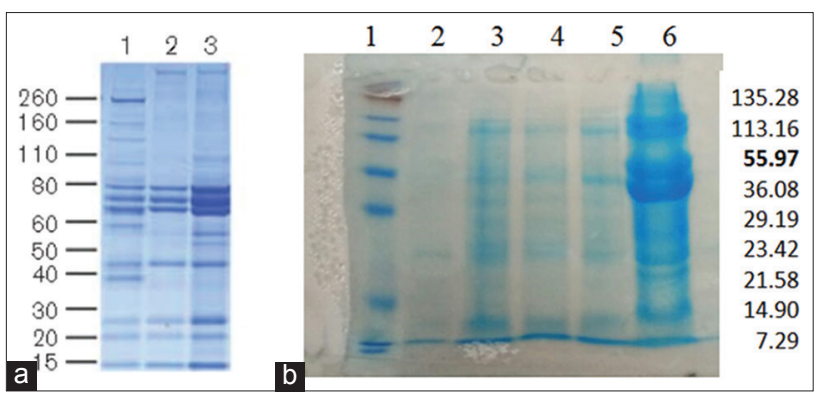

Figure-1: Protein profile of Newcastle disease virus (NDV) using sodium dodecyl sulfate-polyacrylamide gel electrophoresis (SDS-PAGE) test (Lane 1 left=molecular weight marker); (Lane $2=$ Titer virus $2^{6}$ ), (Lane $3=$ Titer virus $\left.2^{7}\right) ;\left(\right.$ Lane $4=$ Titer virus $\left.2^{8}\right)$; (Lane $5=$ Titer virus $\left.2^{9}\right)$; (Lane $6=$ Titer virus $2^{10}$ ). (a) Protein profile of allantoic fluid (AF) of no NDV-infected embryo as identified using SDS-PAGE, first lane [16]. (b) Protein profile of AF of NDVinfected embryo of ECEs $9-11$ days of age. 


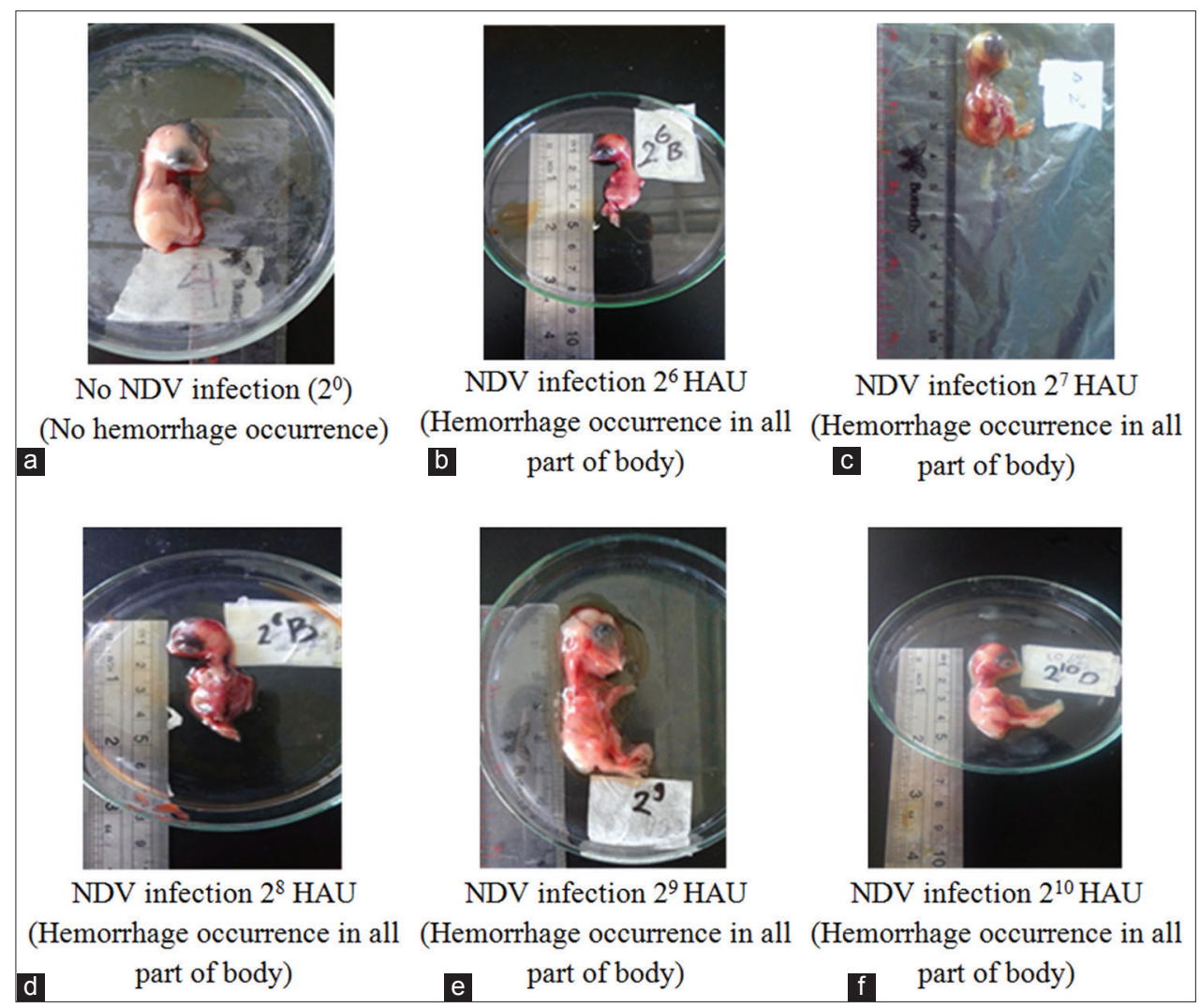

Figure-2: Gross pathology of the embryo in level infection of ND virus. (a) No virus infection $\left(2^{\circ}\right)$ showed no hemorrhage in all part of the body; (b-f) inoculation with virus titer $2^{6}, 2^{7}, 2^{8}, 2^{9}$, and $2^{10}$ hemagglutination unit showed hemorrhage in all part of the body.

Table-1: Average chicken embryo size as affected by the level of NDV infection.

\begin{tabular}{lc}
\hline Treatment & Average \pm SD $(\mathbf{c m})$ \\
\hline No viral infection $\left(2^{0}\right)$ & $3.96^{\mathrm{a}}$ \\
$2^{6} \mathrm{HAU}$ & $5.26^{\mathrm{b}}$ \\
$2^{7} \mathrm{HAU}$ & $4.92^{\mathrm{b}}$ \\
$2^{8} \mathrm{HAU}$ & $5.26^{\mathrm{b}}$ \\
$2^{9} \mathrm{HAU}$ & $4.88^{\mathrm{b}}$ \\
$2^{10} \mathrm{HAU}$ & $5.08^{\mathrm{b}}$ \\
\hline
\end{tabular}

Values with different superscript in the same column showed significantly different $(p<0.05), S D=$ Standard deviation. NDV=Newcastle disease virus

Trypsin can be found in the respiratory and digestive tract. Trypsin breaks down the F protein of NDV making it easier for NDV to replicate. Cleavage site sequence of the $\mathrm{F}$ protein of NDV, which increases the virulence of the NDV [18]. The protein profile of NDV-infected chicken embryos was clearly seen at infection level of $2^{7} \mathrm{HAU}$ or higher.

The results of research are contrary to that done by Al-Garib et al. [19], which explains that NDV infection can lead to weight loss. NDV strains can replicate in the respiratory and digestive systems but preferably the digestive system. NDV can cause mass destruction of lymphoid organs in the gastrointestinal tract characterized by the presence of ulcers in the digestive epithelium. NDV could infect the digestive system causing proventriculus and intestinal hemorrhage and edema [20]. According to Kapczynski et al. [21] that pathological changes are associated with malabsorption syndrome in chickens as characterized by epithelial cell degeneration and crypta, also villus atrophy. The depth of the villi will increase in the infected embryo. Villi serve to absorb nutrients of food. Increased peristaltic movement of the intestines that decreased nutrient absorption and finally resulting in weight loss. NDV can also replicate in the respiratory system and lymphoid organs such as lung, spleen, fabricius, and thymus exchanges [6].

The ECEs used in this experiment did not contain antibodies against NDV because antibodies neutralized the virus and protect the embryo through two ways, first by binding infected cells, then reduce the production of progeny virus, and the second by releasing the progeny virus so that it will inhibit the spread of the virus [22].

The velogenic of NDV caused hemorrhage in all body systems. Hemorrhage was especially in the occipital part [7]. The infective dose of the ECEs was $2^{3}$, whereas the infective dose in the chicken was $2^{6}$ [23]. This was in accordance with Ahamed et al. [24] that the velogenic of NDV showed clinical symptoms of hemorrhage and necrosis of the respiratory tract and digestion. It also disrupted the nervous system [25]. Clinical symptoms appear varied depending on the strain of the virus, avian species and age, recurrent disease, and maternal immunity [2]. The results showed that all variations velogenic of NDV 
titer infected in ECEs caused the death of embryo on the $2^{\text {nd }}$ day. Death of embryos $(100 \%)$ with a titer of NDV strains velogenic variation occurs within $48 \mathrm{~h}$. This was consistent with Balachandran et al. [7] that NDV strains caused high mortality varies velogenic $60 \mathrm{~h}-90 \mathrm{~h}$ in ECEs infected with $2^{5}-2^{7}$ NDV titers. This statement did not correspond to Mulisa et al. [26] that isolates velogenic NDV in birds caused death at 3-6 days post-infection. Immunity of embryo was strongly influenced by the immune system of the embryo, the amount of virus, and the virus strain.

The growth of the NDV titer $10^{3.9}$ TCID can be observed in Vero monolayer cells histopathologically showed the presence of cytopathic effect (CPE) followed by the formation of multinucleated giant cells (MGCs) 30-40 h after infection. CPE is characterized by granular cytoplasm around infected cells, development of microplaque, intracytoplasmic, vacuolization, and syncytia formation [27].

According to research conducted by Putra et al. [25], the embryos infected by the virus ND isolate Salatiga appear dark red and skin looks wet. Subcutaneous tissue containing blood and blood vessels stand out.

Embryonic mortality was influenced by several factors such as embryonic age, viral dosage, embryo's immune status, incubation time, and environmental temperature. Infectious viruses can survive for months at room temperature in chicken eggs infected with the virus [8].

The NDV has an envelope, the single-stranded negative-sense RNA genome consists of six genes that encode the structural proteins and $\mathrm{V}$ and $\mathrm{W}$ proteins of the $\mathrm{P}$ gene called RNA editing [26].

Protein matrix (M), fusion (F) and hemagglutinin-neuraminidase (HN) of NDV related to the viral coat proteins which $\mathrm{M}$ function to perform virus budding formation, whereas $\mathrm{F}$ and $\mathrm{HN}$ protein mediate the entry and release of NDV. The virulence of NDV is determined by the amino acid composition of multiple basic amino acids from the breakdown of protein protease F [27]. F protein located on the virus envelope or outer sheath which mediates $F$ of the virus with the host cell membrane. Protein F with host cells at neutral $\mathrm{pH}$ causes multinucleate (synticia) conditions that result in tissue necrosis and viral spread [5].

NDV protein profile showed molecular weight molecules tightly 7.29-135.28 Kda. This study contradicts Khan et al. [14] that the weight of NDV 12.5-181 Kda molecule uses 24-26 virus titers. During replication, NDV breaks down the glycoprotein precursors F0 to F1 and F2 for virus progeny to become infectious which can only occur in AF compared to culture cells. The NDV has six genes that affect viral pathogens, namely nucleoprotein, phosphoprotein $(\mathrm{P}), \mathrm{M}$, (F), HN, and polymerase (L). Virulence of the NDV ranges from avirulent (lentogenic), to mildly virulent (mesogenic) and highly virulent (velogenic), which can infect birds both naturally and experimentally [26].
Based on the results of the study showed that various variations of virulent titers of NDV $\left(2^{6}-2^{10}\right)$ in ECEs showed death on the $2^{\text {nd }}$ day post-infection and the presence of hemorrhage but no significant difference to embryonic length than without infection. Recent studies have shown that a new protein profile is visible on the NDV $2^{7}$ titers.

\section{Conclusion}

It was concluded that NDV infection of all different level decreased health conditions of chicken embryo of ECEs of 9-11 days old. Different level of NDV infection of ECEs of 9-11 days old showed no significantly different embryo profiles. However, all of the NDV-infected embryos were shorter, death on the $2^{\text {nd }}$ day, and suffered more hemorrhage on all body surfaces than uninfected NDV embryos.

\section{Authors' Contributions}

DQ was responsible for controlling the course of studies and analyzing data. SM did SDS-PAGE analysis. ES performed ND virus inoculation and harvested the results. MAL did HA and HI test. All authors read and approved the final manuscript.

\section{Acknowledgments}

The authors acknowledged to the Ministry of Research, Technology, and Higher Education, the Republic of Indonesia for providing funding for this study with contract No. 460.58/UN10.C10/2017.

\section{Competing Interests}

The authors declare that they have no conflicts of interests.

\section{References}

1. Mohammadamin, O.G. and Qubih, T.S. (2011) Histopathology of virulent newcastle disease virus in immune broiler chickens treated with $\mathrm{IMBO}^{\circledR}$. Iraqi J. Vet. Sci., 25: 9-13.

2. Abdisa, T. and Tagesu, T. (2017) Review on Newcastle disease of poultry and it's public health importance. J. Vet. Sci. Technol., 8: 441.

3. Orsi, M.A., Júnior, D., Reischak, D., Da Silva, H.A., Spilki, F.R., Buzinaro, M.G. and Arns, C.W. (2009) Newcastle disease virus vaccine strains: Immunogenicity is not influenced by ICPI. Braz. J. Poult. Sci., 11: 129-133.

4. Yang, H.M., Zhao, J., Xue, J., Yang, Y.L. and Zhang, G.Z. (2017) Antigenic variation of LaSota and genotype VII newcastle disease virus (NDV) and their efficacy against challenge with velogenic NDV. Vaccine, 35: 27-32.

5. Ganar, K., Das, M., Sinha, S. and Kumar, S. (2014) Newcastle disease virus: Current status and our understanding. Virus Res., 184: 71-81.

6. Kang, Y., Minsha, F., Xiaqiong, Z., Xu, D., Bin, X., Pei, G., Yulian, L., Li, Y. and Tao, R. (2016) Newcastle disease virus infection in chicken embryonic fibroblasts but not duck embryonic fibroblasts is associated with elevated host innate immune response. Virol. J., 13: 41.

7. Balachandran, P., Srinivasan, P., Sivaseelan, S., Balasubramaniam, G.A. and Murthy, T.R.G. (2014) Isolation and characterization of newcastle disease virus from vaccinated commercial layer chicken. Vet. World, 7: 457-462.

8. Romanini, C.E.B., Exadaktylos, V., Tong, Q., McGonnel, I., Demmers, T.G.M., Bergoug, H., Eterradossi, N., Roulston, N., Garain, P., Bahr, C. and Berckmans, D. (2013) Monitoring the hatch time of individual chicken embryos. 
Poult. Sci., 92: 303-309.

9. OIE. (2012) Manual of Diagnostic Tests and Vaccines for Terrestrial Animals (Mammals, Birds and Bees). $7^{\text {th }}$ ed., Vol. 2. OIE, Paris.

10. Alexander, D.J., Manvell, R.J. and Parsons, G. (2006) Newcastle disease virus (strain herts 33/56) in tissues and organs of chickens infected experimentally. Avian Pathol., 35: 99-101.

11. Bilal, E.S.A., Elnasri, I.M., Alhassan, A.M., Khalifa, K.A., Elhag, J.I. and Ahmed, S.O. (2014) Biological pathotyping of newcastle disease viruses in Sudan 2008-2013. J. Vet. Med., 2014: 1-4.

12. OIE. (2012) Newcastle Disease (Infection with Newcastle Disease Virus). Ch. 2.3.14. OIE, Paris.

13. Shah, A.M., Shah, A.R., Mirbahar, K.H., Naeem, M., Jatoi, A.S. and Wagan, B. (2016) Virulence of newcastle disease virus in different species through various dilutions. Sci. Int. (Lahore)., 28: 1255-1258.

14. Khan, H.A., Siddique, M., Rahman, S.U., Arshad, M. and Ashraf, M. (2005) Comparative molecular characterization of field and vaccinal strains of newcastle disease virus. Pak. Vet. J., 25: 3.

15. Sambodo, P., Joko, P., Kurniasih, K. and Sudarmanto, I. (2018) In vitro potential anthelmintic activity of Biophytum petersianum on Haemonchus contortus. Vet. World, 11(1): 1-4.

16. Perozo, F., Pedro, V., Roser, D., Claudio, L.A. and Linda, B.P. (2008) The VG/GA strain of newcastle disease virus: Mucosal immunity, protection against lethal challenge and molecular analysis. Avian Pathol., 37(3): 237-245.

17. Dewi, R.E. and Surachmi, S. (2017) Pathology and immunohistochemistry study of newcastle disease field case in chicken in Indonesia. Vet. World, 10(9): 1066-1071.

18. Read-Snyder, J., Edens, F.W., Cantor, A.H., Pescatore, A.J. and Pierce, J.L. (2009) Effect of dietary selenium on small intestine villus integrity in reovirus-challenged broilers. Int. J. Poult. Sci., 8(9): 829-835.
19. Al-Garib, S.O., Gielkens, L.J., Gruys, E. and Koch, G. (2003) Review of newcastle disease virus with particular references to immunity and vaccination. Worlds Poult. Sci. J., 59: 185-200.

20. Dimitrov, K.M, Afonso, A.L, Yu, Q. and Miller, P.J. (2017) Newcastle disease vaccines-a solved problem or a continuous challenge? Vet. Microbiol., 206: 126-136.

21. Kapczynski, D.R., Afonso, C.L. and Patti, J.M. (2013) Immune responses of poultry to Newcastle disease virus. Dev. Com. Immunol., 41: 447-453.

22. Gohm, D.S, Thür, B., Hofmann, M.A. (2000) Detection of newcastle disease virus in organs and faeces of experimentally infected chickens using RT-PCR. Avian Pathol., 29: 143-152.

23. Rue, C.A., Leonardo, S., Ingrid, C., Corrie, C.B., Kapczynski, D.R., Suarez, D.L., Daniel, J.K., Miller, P.J. and Afonso, C.L. (2011) Virulent newcastle disease virus elicits a strong innate immune response in chickens. J. Gen. Vir., 92: 931-939.

24. Ahamed, T., Hossain, K.M., Billah, M.M., Islam, K.M.D., Ahasan, M.M. and Islam, M.E. (2004) Adaptation of newcastle disease virus (NDV) on Vero cell line. Int. J. Poult. Sci., 3(2): 153-156.

25. Putra, H.H., Michael, H.W., Tri, U. and Kurniasih, K. (2012) Case study of macroscopic and microscopic lesion of chicken embryo infected with virulence Newcastle disease viruses. J. Sain Vet., 30(1): 1-9.

26. Mulisa, D.D., Menbere, K., Redeat, B.A., Melaku, S.K., Alice, F., Alireza, H., Tesfaye, R.C. and Hassen C.C. (2014) Characterization of Newcastle disease virus and poultry-handling practices in live poultry markets, Ethiopia. Springerplus, 3: 459.

27. Dortmans, J.C.F., Rottier, P.J.M., Koch, G. and Peeters, B.P.H. (2011) Passaging of a newcastle disease virus pigeon variant in chickens results in selection of viruses with mutations in the polymerase complex enhancing virus replication and virulence. J. Gen. Virol., 92: 336-345. 